Pendidikan Agama Islam... | 75

\title{
PENDIDIKAN AGAMA ISLAM BERBASIS SIRAH NABAWIYAH
}

\author{
Toha Makhshun 1)* \\ ${ }^{1}$ Universitas Islam Sultan Agung \\ *Email: toha_m@unissula.ac.id
}

\begin{abstract}
The article aims to explain and describe the concept of Islamic education which imitates the Prophet's model in educating friends. The method used is descriptive qualitative analysis, namely describing the data accompanied by critical analysis. The results of the research can beconcluded that in general, Islamic religious education based on sirah Nabawiyah at the Kuttab Al-Fatih Semarang Foundation is carried out by teachers very well and efficiently, this can be proven from several things, namely: 1). Planning Based on Sirah Nabawiyah at the Kuttab Al-Fatih Semarang Foundation can be said to be very good and efficient, because in implementing planning in learning Kuttab teachers really pay attention to the procedures that will be used and applied to good students. 2) The implementation of islamic Learning Based on Sirah Nabawiyah at the Kuttab Al-Fatih Semarang Foundation is very good and efficient, because most of the indicators contained in learning have been carried out by the teacher both from the aspects of preliminary activities, core activities and closing activities are in accordance with Kuttab procedures.
\end{abstract}

Keywords: Islamic Education, Sirah Nabawiyah

\begin{abstract}
Abstrak
Artikel ini bertujuan untuk menjelaskan dan mendiskripsikan konsep pendidikan agama Islam yang meniru model Rasulullah dalam melakukan pendidikan kepada para sahabat. Metode yang digunakan adalah analisis deskriptif kualitatif, yaitu menggambarakan data disertai dengan analisis kritis. Hasil penelitiannya dapat disimpulkan bahwa secara garis besar Pendidikan Agama Islam yang berbasis sirah Nabawiyah di Yayasan Kuttab Al-Fatih Semarang yang dilaksanakan oleh para guru dengan sangat baik dan efisien, hal ini dapat dibuktikan dari beberapa hal yaitu: 1). Perencanaan Pembelajaran Berbasis Sirah Nabawiyah di Yayasan Kuttab Al-Fatih Semarang dapat dikatakan sangat baik serta efisien, sebab dalam pelaksanakan perencanaan dalam pembelajaran guru Kuttab sangat memperhatikan prosedur yang akan digunakan dan diterapkan pada peserta didik baik. 2).Pelaksanaan Pembelajaran Berbasis Sirah Nabawiyah di Yayasan Kuttab Al-Fatih Semarang sangat baik dan efisien, sebab sebagian besar indikator yang terdapat dalam pembelajaran sudah dilaksanakan oleh guru baik dari aspek kegiatan pendahuluan, kegiatan inti maupun kegiatan penutup sudah sesuai dengan prosedur Kuttab.
\end{abstract}

Kata Kunci: Pendidikan Agama Islam, Sirah Nabawiyah

\section{PENDAHULUAN}

Pendidikan merupakan persoalan penting bagi semua umat manusia. Menurut alGhazali sebagaimana diungkap oleh Fatiyah Hasan Sulaiman bahwa pendidikan sebagai sarana untuk menyebarluaskan keutamaan, sebagai media untuk mendekatkan umat manusia kepada Allah dan sarana kemaslahatan untuk membina umat (Sulaiman, 1993), dan pendidikan dipandang sebagai proses untuk meninggikan 
harkat dan martabat manusia (Sujana, 1989). Pendidikan dalam Islam diarahkan untuk menjaga fitrah manusia agar manusia mampu memikul tanggung jawab dalam memakmurkan bumi, yaitu sebagai khalifah Allah di muka bumi. Kata fitrah diderivasi dari kata fathara yang memiliki makna menciptakan pola dasar, yang masih memerlukan untuk disempurnakan (Achmadi, 2010)

Peraturan Pemerintah No. 55 tahun 2007 tentang pendidikan agama dan pendidikan keagamaan, memiliki tujuan untukmembawa perbaikan dunia pendidikan, yang mana satuan pendidikan diberi kewenangan untuk menambah muatan pendidikan agama sesuai kebutuhan materi tambahan, jam pelajaran, kedalaman materi). Hal tersebut mengandung pengertian bahwa satuan pendidikan berwenang mengembangkan dan mengelola sesuai dengan visi misi satuan pendidikan, juga dari sudut peserta didik, dapat diberikan materi sesuai dengan kebutuhan dan sesuai dengan pengalaman sehari-hari (Muflihin, 2020).

Hal sesuai dengan tujuan pendidikan agama Islam, yaitu memberikan nilai spiritual uluhiyah. Agama bukan hanya disampaikan dalam rumusan konsep atau teori), namun dirumuskan dalam perbuatan-perbuatan nyata yang teraktualisasi dalam diri peserta didik menyangkut aspek kognitif, afektif, dan psikomotorik. Disadari atau tidak pembelajaran pendidikan Agama Islam selama ini memiliki banyak celah dan kekuarangan, mulai alokasi waktu yang terbatas, materi yang masih terfokus pada aspek kognitif, dan lemahnya sumberdaya guru Pendidikan Agama Islam. Salah satu upaya untuk memperbaiki masalah tersebut, adalah dengan mengembangkan kurikulum.

Kurikulum adalah suatu progam pendidikan yang dirancangkan secara sistematik berdasarkan norma yang berlaku, sebagai pedoman pelaksanaan pembelajaran (Dakir, 2004). Yayasan Kuttab Al-Fatih merupakan salah satu lembaga pendidikan yang menerapkan konsep pendidikan yang berbasis sirah Nabawiyah atau pendidikan ala Rasulullah dan para sahabatnya dalam pembelajaran.

Yayasan Kuttab Al-Fatih hadir untuk mencoba melahirkan generasi yang mana generasi tersebut pernah ada dalam sejarah Islam, mulai zaman Rasulullah sampai zaman kejayayan Islam. Kunci dari pendidikan Islam itu sendiri berasal dari Rasulullah SAW, yaitu bagaimana beliau menerapkan dan menggunakan metode atau konsep pendidikan Islam dalam mendidik generasi. 
Berawal dari hal di atas, penulis melakukan penelitian tentang Pendidikan Agama Islam berbasis Sirah Nabawiyah di Kuttab Al Fatih Semarang, dengan fokus penelitian bagaimana pelaksanaan pendidikan agama Islam berbasis sirah Nabawiyah di Yayasan Kuttab Al-Fatih Semarang.

\section{METODE}

Penelitian yang digunakan adalah penelitian kualitatif, jenis penelitian untuk mempermudah dalam mengumpulkan data, fakta dan informasi yang digunakan penulis adalah berupa penelitian lapangan (field research), yaitu suatu penelitian yang dilakukan dengan terjun langsung ke lapangan untuk melihat secara langsung keadaan di lapangan, mencari informasi-informasi yang mendekati kebenaran atau konkrit guna memperoleh data yang mendalam dan bermakna. Sedangkan aspek penelitian yang diteliti meliputi aspek perencanaan yaitu kegiatan pembelajaran yang disusun ke dalam RKK (Rencana Kegiatan Kuttab) yang dibuat secara tematik dan dikaitkan dengan konsep pendidikan Rasulullah dan aspek pelaksanaan yang meliputi kegiatan pembukaan, kegiatan inti, dan kegiatan penutup.

\section{HASIL DAN PEMBAHASAN}

Pada bagian ini, yaitu hasil penelitian dan pembahasan ada dua aspek yang akan yang menjadi fokus penulis, yaitu perencanaan dan pelaksanaan.

a. Perencanaan

Perencanaan pembelajaran Pendidikan Agama Islam di Yayasan Kuttab AlFatih diwujudkan ke dalam RKK, yaitu suatu perencanaan yang dibuat oleh setiap guru Kuttab berkenaan dengan hal-hal yang akan diterapkan dan digunakan dalam kegiatan pembelajaran serta disesuaikan dengan panduan dari koordinator Kuttab.

Dengan perencanaan kegiatan harian atau kegiatan pembelajaran yang dijadikan sebagai objek dalam penelitian, maka peneliti akan mengetahui bagaimana konsep pendidikan berbasis sirah Nabawiyah dalam sistem pembelajaran di Kuttab Al-Fatih Semarang sebab hal tersebut berkenaan dengan pelaksanaan pendidikan agama Islam berbasis sirah Nabawiyah di Kuttab AlFatih.

Berdasarkan dari hasil wawancara diperoleh data, bahwa pembelajaran yang menggunakan serta menerapkan konsep atau model pendidikan yang 
dilakukan oleh Rasulullah di masa kejayaan Islam dulu di dalam mendidik para sahabat, sehingga sistem pendidikan di Kuttab Al-Fatih ini lebih condong pada pendidikan Islam. Akan tetapi di masa yang sudah modern ini, pendidikan Islam bisa diapresiasikan dan diaplikasikan menjadi Pendidikan Agama Islam. Dengan konsep pendidikan yang berbasis sirah Nabawiyah inilah Kuttab Al-Fatih mencoba untuk menerapkan serta mengaplikasikan konsep pendidikan Rasulullah ke dalam pembelajaran, sebab konsep pendidikan yang pertama kali ditanamkan oleh Rasulullah adalah pendidikan tentang penanaman keimanan, sehingga dari kurikulum iman inilah akan terwujud Pendidikan Agama Islam yang berbasis sirah Nabawiyah di Kuttab Al-Fatih semarang ini serta tujuan dalam suatu lembaga pendidikan akan terwujud yaitu mewujudkan dan melahirkan generasi yang khaira ummah di usia belia.

Konsep pendidikan yang berbasis sirah Nabawiyah ini digunakan sebagai acuan dalam pendidikan di Kuttab Al-Fatih sebab di zaman sekarang ini banyak sekali sekolah-sekolah pada umumnya yang tidak memperhatikan pendidikan awal pada anak terlebih dalam penanaman tentang keimanan, bahkan jarang sekali sekolah umum mengajarkan mengenai hal tersebut. Padahal penanaman kefaham tentang keimanan pada awal pendidikan anak sangatlah penting bagi keberlangsungan kehidupan mereka di masa yang akan mendatang. Hal ini dapat dilihat dari hasil wawancara secara langsung dengan guru koordinator iman, yaitu:

Kuttab Al-Fatih merupakan salah satu lembaga pendidikan yang menggunakan kurikulum tersendiri, yaitu kurikulum iman dan kurikulum Qur'an. Adapun kurikulum Kuttab yang lebih mengarah pada pendidikan agama Islam yang berbasis sirah Nabawiyah adalah pada kurikulum iman, sebab dalam pendidikan agama Islam sendiri terdapat materi tentang keimanan. Dalam pelaksanaan kurikulum iman ini diwujudkan dalam bentuk RKK, yang mana RKK disusun dengan merujuk atau berpedoman pada konsep pendidikan Rasulullah serta menggunakan metode tematik, yaitu dibagi menjadi beberapa tema lalu dibentuk lagi ke dalam sub tema yang mana setiap sub tema dikaitkan dengan juz 30.

Sehingga di setiap pembelajaran peserta didik selalu dikaitkan dengan keimanan kepada Allah, seperti halnya contoh tema tentang permukaan bumi 
dengan sub tema gunung yang dikaitkan dengan surat Al-Qari'ah ayat 5 dan disela-sela pembelajaran guru selalu mengkaitkan perilaku peserta didik atau ilmu yang diajarkan dengan cerita-cerita Islami atau teladan Rasulullah. Dari sinilah anak belajar tentang keimanan kepada Allah dan juga lebih mengenal sosok Rasulullah lebih mendalam, tidak hanya ilmu tentang keimanan saja yang diajarkan kepada peserta didik akan tetapi ilmu-ilmu murofaqot seperti IPA, matematika dan bahasa juga diajarkan dalam satu tema atau sub tema tersebut.

Perencanaan pendidikan agama Islam yang berbasis sirah Nabawiyah dalam kurikulum iman di Kuttab Al-Fatih mencakup kegiatan secara umum yang dilakukan ketika raker (rapat kerja), yang biasa dilaksanakan di awal semester atau di awal tahun pembelajaran, hal tersebut dilakukan oleh para guru Kuttab guna menyusun kegiatan pembelajaran terpadu selama satu tahun ke depan. Adapun perencanaan yang disusun dalam kegiatan iman meliputi kegiatan pembelajaran, review, ujian tema, ujian review semester dan ujian akhir semester.

Selanjutnya adalah perencanaan dalam kegiatan persemester yang dilaksanakan sebagai menunjang penanaman keimanan pada peserta didik setelah kegiatan pembelajaran, yang meliputi: hunting class, yaitu peserta didik diajak untuk keluar kemudian menuju ke tempat tertentu dengan memperlajari tentang tempat tersebut berkenaan dengan materi yang sudah dipelajari di kelas, mabit/muqayyam (berkemah) yang diadakan satu semester sekali sebagai puncak pembelajaran selama satu semester dengan mengaplikasika ilmu yang sudah didapat saat pembelajaran yang mana kegiatan tersebut diikuti oleh santri Kuttab awal 3 dan Qonuni 4, pra-mabit yang diikuti oleh kuttab awal 1 dan kuttab awal 2. Sedangkan perencanaan yang terakhir dilakukan adalah perencanaan kegiatan harian yaitu kegiatan pembelajaran setiap hari yang dilaksanakan melalui raker (rapat kerja), yang mana dalam raker tersebut menyangkut pembuatan kalender pembelajaran dan penyusunan RKK.

Sebelum proses pembelajaran dilaksanakan guru atau Ustadz/Ustadzah terlebih dahulu membuat perencanaan kegiatan Kuttab (RKK), yang mana dalam pembuatan RKK tersebut harus mencakup materi yang akan digunakan sesuai dengan modul yang digunakan, tema apa yang akan dipelajari dan sub tema apa yang akan dikaji sesuai tema pembelajaran, ayat yang akan dipelajari sesuai 
dengan tema, target iman yang akan dibidik atau yang akan ditanamkan pada diri anak, target ilmu lain yang terdapat di ayat tersebut. Untuk mencapai target iman atau bidikan iman tersebut, langkah-langkah yang dilakukan oleh guru iman dalam penyusunan RKK adalah dengan menentukan tema yang akan digunakan dalam pembelajaran terlebih dahulu, yang mana tema tersebut berdasarkan modul alam yang dijadikan sebagai panduan dalam materi Kuttab.

Setelah tema ditentukan sesuai dengan modul alam, tema dibagi menjadi beberapa sub tema yang mana dalam setiap sub tema dikaitkan dengan ayat alQur'an atau dicarikan ayat-ayat al-Qur'an yang membahas tentang sub tema tersebut, akan tetapi lebih dikhususkan pada juz 30, kemudian guru menentukan kompetensi dasar yang akan dicapai atau dalam RKK dikenal dengan istilah bidikan iman pada anak, menyesuaikan media yang akan digunakan dengan sub tema pembelajaran, mencari ilmu-ilmu murafaqat yang terkandung dalam ayat yang dikaji sesuai dengan sub tema, serta menyiapkan cerita-cerita Islami yang berhubungan dengan sub tema yang akan disampaikan dalam pembelajaran yang mana cerita tersebut akan dikaitkan dengan kehidupan peserta didik atau santri Kuttab.

Seperti halnya contoh perencanaan pembelajaran pada Kuttab awal yang menggunakan tema permukaan bumi dan sub tema gunung, yang mana dari sub tema tersebut dikaitkan dengan surat al-Qari'ah ayat 5 yang di dalamnya mengandung penjelasan mengenai gunung dan unsur-unsurnya serta menjelaskan juga tentang keimanan kepada Allah dan hari kiamat. Di samping itu pula terdapat ilmu murafaqat berkaitan dengan IPA yang menjelaskan tentang unsur-unsur pada gunung dan bagaimana cara gurung itu meletus serta dalam praktiknya guru menggunakan alat media kapas sebagai perumpamaan dalam menggambarkan keadaan pada hari kiamat berkenaan dengan suart al-Qari'ah tersebut.

Penyusunan RKK yang dilakukan oleh guru iman di Yayasan Kuttab Al-Fatih ini tidak jauh berbeda dengan penyusunan RPP pada sekolah-sekolah pada umumnya, hanya saja yang menjadi pembeda dalam pembelajaran di Kuttab adalah materi yang disampaikan oleh guru Kuttab disesuaikan dengan jenjang usia anak seperti halnya pada Kuttab awal yang menggunakan modul alam semesta sebagai panduan dalam materi pembelajaran. Hal inilah yang menjadi 
salah satu faktor pendukung dalam memasukan bidikan iman yang ditargetkan pada hati anak, sehingga dengan begitu pembelajaran yang diberikan oleh guru tidak terbuang dengan sia-sia akan tetapi akan tertanam dan dipraktikan secara langsung oleh peserta didik atau santri Kuttab baik di lingkungan sekolah maupun di rumah.

Setelah RKK selesai disusun, RKK akan diplenokan terlebih dahulu oleh Ustadz/Ustadzah yang membuatnya sebelum diterapkan dalam pembelajaran dengan cara dipresentasikan bersama Ustadz Ustdzah lainnya yang dilakukan satu pekan sekali dalam rapat kerja yang disebut dengan forum pleno. Sehingga dengan begitu jika terdapat kesalahan atau ketidak cocokan dalam pembuatan RKK, maka Ustadz/Ustadzah yang lain akan memberikan masukan mengenai RKK tersebut akan tetapi yang memutuskan adalah PJ Syar'i Kuttab, hal ini bertujuan agar RKK yang digunakan sesuai dengan kemampuan dan keadaan peserta didik atau santri Kuttab dan kaidah dalam Islam. Adapun materi ajar yang digunakan dalam pembuatan RKK diambil dari ayat-ayat Al-Qur'an yang diajarkan secara tematik, hadits Nabi, modul alam semesta, modul ikrar Kuttab, modul Kuttab satu, artikel Islami, jurnal serta buku-buku Islami yang berkenaan dengan tema.

Berdasarkan data yang peneliti peroleh dari hasil wawancara kepada Ustadz Nur Rokhim sebagai koordinator iman dan observasi kepada guru iman berkenaan dengan perencanaan pendidikan agama Islam yang berbasis sirah Nabawiyah di Kuttab Al-Fatih ini ada dua macam perencanaan yang digunakan, yang mana hal tersebut dilakukan oleh para guru Kuttab guna menunjang pembelajaran tentang penanaman keimanan secara mendalam terhadap peserta didik.

Sebab dengan perkembangan di zaman sekarang ini mengakibatkan banyak anak yang kehilangan kefahaman tentang keimanan, terlebih dalam konteks pendidikan di Indonesia ini yang lebih mengikuti pola pendidikan orang-orang barat sehingga karakter pendidikan yang semestinya dimiliki dan diterapkan dalam pendidikan di Negara ini telah menghilang sedikit demi sedikit selaras dengan berkembangnya teknologi. Oleh karena itu Kuttab Al-Fatih mencoba untuk menerapakan suatu konsep pendidikan yang mana konsep pendidikan tersebut pernah digunakan dan dipraktikan oleh Rasulullah ke dalam suatu pembelajaran guna melahirkan generasi gemilang di usia belia. 
Perencanaan yang dilakukan dalam pembelajaran iman di Kuttab ada dua macam, yaitu perencanaan harian yang meliputi kegiatan pembelajaran dan perencanaan persemester. Perencanaan harian dalam pelaksanaan kegiatan pembelajaran disusun oleh para guru iman ke dalam RKK (Rencana Kegiatan Kuttab) dapat dibilang sudah sangat efisien, sebab dalam penyusunan RKK yang dilakukan oleh guru iman sudah sesuai dengan komponen-komponen dalam perencanaan pembelajaran pada umumnya. Adapun komponen-komponen yang terkandung dalam perencanaan sesuai dengan ketentuan dalam Standar Nasional Pendidikan, yamg meliputi Identitas mata Pelajaran, standar kompetensi, kompetensi dasar, indikator capaian kompetensi, tujuan, matari, waktu, metode dan kegiatan pembelajaran.

Pada dasarnya tahap perencanaan yang dilakukan oleh guru Kuttab hampir sama dengan tahap perencanaan pada umumnya, akan tetapi dalam perencanaan pembelajaran di Kuttab Al-Fatih Semarang lebih mengarah pada kurikulum di Kuttab yang mana dalam perencanaanya guru benar-benar memperhatikan materi yang akan disampaikan disesuaikan dengan tingkat kemampuan yang dimiliki oleh peserta didik serta dalam memilih materi pembelajaran untuk RKK merujuk pada buku modul alam semesta yang digunakan sebagai panduan dalam pembuatan RKK, dan setelah itu RKK harus diplenokan terlebih dahulu kepada pada guru dan PJ Syari'ah Kuttab sehingga RKK yang sudah diplenokan inilah yang nantinya akan digunakan sebagai acuan dalam pembelajaran oleh guru.

Hal inilah yang menjadikan konsep pendidikan di Kuttab Al-Fatih berbeda dengan sekolah-sekolah pada umumnya. Dengan begitu antara RKK Kuttab dengan komponen perencanaan dalam pembelajaran secara umum saling berkesinambungan antara satu sama lain, sebab dalam penyusunannya guru Kuttab sangat memperhatikan unsur-unsur yang digunakan sesuai dengan arahan dari koordinator iman.

Sedangkan dalam perencanaan kegiatan persemester yang dilakukan dalam pembelajaran di Kuttab Al-Fatih sudah dapat dikatakan sangat baik dan efisien, sebab kegiatan yang dilakukan di setiap akhir semester ini diadakan sebagai penunjang dalam kegiatan harian atau pembelajaran dan sangat memberikan dampak yang positif serta pengalaman yang mendalam pada diri peserta didik, sehingga tujuan dalam suatu pembelajaran dapat tercapai secara keseluruhan. 
Hal tersebut selaras dengan Undang-Undang No.20 tahun 2003 pasal 3 tentang Sistem Pendidikan Nasional yang menjelaskan bahwa tujuan dari pendidikan nasional adalah untuk mengembangkan potensi yang dimiliki oleh peserta didik agar menjadi manusia yang bertaqwa serta beriman kepada Tuhan Yang Maha Esa, berkahlakul karimah, menjadi manusia yang berilmu serta menjadi warga Negara yang demokratis dan bertanggung jawab. Sehingga ada relevansi yang saling signifikan antara perencanaan yang dilakukan di Kuttab AlFatih Semarang dengan tujuan pendidikan nasional.

b. Pelaksanaan

Pendidikan Agama Islam yang berbasis sirah Nabawiyah di Yayasan Kuttab Al-Fatih Semarang dilaksanakan dalam kurikulum iman, sebelum proses pembelajaran guru atau Ustadz/Ustadzah membuat RKK yang telah di-plenokan digunakan sebagai acuan dalam pembelajaran. Kurikulum iman merupakan salah satu kurikulum yang digunakan dalam konsep pendidikan di Kuttab Al-Fatih, dalam kurikulum iman terdapat beberapa materi yang berkaitan erat dengan pendidikan agama Islam yang mana disusun ke dalam RKK Kuttab yang merujuk pada buku modul alam semesta sebagai panduan utama serta dibagi ke dalam beberapa tema dan di dalamnya dibagi menjadi beberapa sub tema lain yang dikaitkan dengan ayat-ayat dalam al-Qur'an.

Berdasarkan hasil observasi yang peneliti lakukan, langkah-langkah pembelajaran di Kuttab yang disusun dalam RKK pada kelas iman meliputi kegiatan awal atau kegiatan pembuka, kegiatan inti dan kegiatan penutup. Kegiatan awal mencakup: Ustadzah menyiapkan peserta didik atau santri sebelum pembelajaran dimulai dengan merapikan tempat duduk santri, pembukaan (salam, hamdalah, sholawat), Ustadzah menanyakan kabar santri atau peserta didik dengan menggunakan bahasa arab, Ustadzah melakukan presensi terhadap santri, Ustadzah membacakan tujuan dari kompetensi yang akan dicapai dalam pembelajaran, Ustadzah menyuruh para santri untuk menyiapkan alat tulis dan meja sebelum pembelajaran dimulai, dan santri atau peserta didik ditalaqqi jama'i surat Al-Qari'ah ayat: 5 beserta artinya dan diulangulang sampai mereka mampu menghafal.

Kegiatan yang kedua adalah kegiatan inti, yaitu: Ustadzah menanyakan kepada peserta didik atau santri mengenai tema dan sub tema beserta surah yang 
akan dipelajari dan yang sudah dipelajari, Ustadzah menyuruh santri untuk membaca surah Al-Qari'ah ayat 5 dan maknanya secara bersama-sama, Ustadzah memberikan penjelasan tentang surah Al-Qari'ah ayat 5 beserta tafsirannya mengenai tanda-tanda dari hari kiamat dengan cara tanya jawab, Ustadzah melakukan simulasi kepada para santri dengan memberikan kapas untuk disobek-sobek menjadi bagian yang kecil-kecil, lalu para santri diajak keluar kelas untuk mempraktikan materi yang sudah dipelajari di dalam kelas dengan meniup kapas yang sudah disobek tadi sambil memberikan sedikit materi dan pertanyaan kepada santri tentang gambaran hari kiamat, kemudian santri diajak untuk beristighfar dan takbir terhadap ke-Maha Besaran kekuasaan Allah dalam menciptakan segala sesuatu serta menghancurkannya dengan dasyatnya.

Selanjutnya adalah kegiatan penutup, yang mencakup: Ustadzah memberikan pertanyaan kepada santri terkaitan kehidupan Rasulullah dengan memberikan 10 bintang bagi santri yang bisa menjawab dengan benar, Ustadzah memberikan sedikit cerita motivasi tentang para sahabat dan ulama' zaman dulu berkaitan dengan sikap santri, Ustadzah menyuruh para santri untuk merapikan dan mengembalikan alat tulis dan meja, Ustadzah mereview sedikit materi yang telah disampaikan sambil muraja'ah ayat yang sudah dipelajari secara bersama, selanjutnya Ustadzah menutup pembelajaran dengan hamdalah, istighfar dan doa kafaratul majelis lalu mengucapkan salam. Ada beberapa hal yang terkait dalam pelaksanaan Pendidikan Agama Islam berbasis sirah Nabawiyah di Kuttab AlFatih, yaitu:

1) Kegiatan pendahuluan

Kegiatan pendahuluan ini memiliki tujuan untuk menjelaskan kepada peserta didik mengenai surat dalam Al-Qur'an yang akan dipelajari berkaitan dengan sub tema, target iman yang akan dibidik atau yang harus difahami serta ilmu murafaqat yang akan dipelajari oleh peserta didik guna mencapai suatu pembelajaran yang efektif dan efisien.

Kegiatan pendahuluan ini dimulai dengan guru menyiapkan peserta didik atau santri sebelum pembelajaran dimulai dengan merapikan tempat duduk santri, yang mana hal ini dilakukan oleh guru guna melatih peserta didik untuk memiliki sikap mandiri dan saling membantu antara sesama teman. Kegiatan yang selanjutnya adalah pembukaan (salam, hamdalah, 
sholawat), hal ini dilakukan oleh guru guna memusatkan perhatian peserta didik dan menyudahi kegiatan yang telah dilakukan sebelumnya, serta mengajarak peserta didik untuk meluruskan niat dalam belajar sehingga peserta didik menyadari bahwa belajar bukan hanya pergi dari rumah menuju ke sekolah saja akan tetapi belajar yang mereka lakukan hanya untuk mencari ilmu dan ridlo dari Allah semata.

Kemudian guru menanyakan kabar santri atau peserta didik dengan menggunakan bahasa arab dengan melakukan presensi terhadap santri atau peserta didik serta membacakan tujuan dari kompetensi atau bidikan iman yang akan dicapai dalam pembelajaran, hal ini bertujuan untuk menggali semangat peserta didik dalam pembelajaran sehingga tujuan pembelajaran dan bidikan tentang keimanan mampu dicapai secara bersama-sama.

Selanjutnya guru menyuruh para santri untuk menyiapkan alat tulis dan meja sebelum pembelajaran dimulai, dan santri atau peserta didik ditalaqqi jama'i surat Al-Qari'ah ayat: 5 beserta artinya, hal ini dilakukan oleh guru untuk menumbuhkan rasa berbagi kepada sesame teman serta membuat peserta didik mampu untuk menghafal dan memahami ayat yang dipelajari secara bersama-sama.

2) Kagiatan inti

Kegiatan inti atau proses merupakan proses kegiatan inti di dalam pelaksanaan pembelajaran, agar hal-hal yang telah direncanakan dan dirancang akan terealisasikan ke dalam proses pembelajaran ini yang mana bertujuan untuk mencapai kompetensi dasar yang dilakukan secara interaktif, inspiratif, menyenangkan, menantang, memotivasi peserta didik agar peserta didik mampu untuk berpatisipasi secara aktif selama pembelajaran berlangsung.

Dalam pelaksanaan pembelajaran ini guru diharuskan menggunakan dan menerapkan suatu pendekatan atau metode yang disesuaikan dengan karakteristik peserta didik serta mata pelajaran yang akan disampaikan sesuai dengan jenjang Kuttab, sehingga dalam pelaksanaan pembelajaran peserta didik mampu untuk mencapai proses eksplorasi, elaborasi dan konfirmasi (Rusman, 2013). 
Berdasarka pada teori diatas dapat disimpulkan bahwa ada beberapa kegiatan yang terdapat di dalam kegiatan inti, yaitu: Kegiatan eksplorasi, elaborasi dan konfirmasi di dalam pelaksanaan pendidikan Agama Islam yang berbasis sirah Nabawiyah dengan tema permukaan bumi dan sub tema gunung yang sesuai dengan surat Al-Qari'ah ayat 5.

Kegiatan yang pertama adalah kegiatan eksplorasi, yang mana dalam kegiatan eksplorasi ini dilakukan oleh peserta didik dengan mengembangkan pengetahuan yang dimilikinya berkaitan tentang sub tema gunung dan tandatanda dari hari kiamat. Kegiatan ini bertujuan untuk menguji kemampuan mengingat, kecakapan serta keaktifan peserta didik terkait sub tema yang dipelajari dalam pembelajaran, sehingga dengan begitu guru akan lebih mudah dalam menyampaikan materi pembelajaran.

Kegiatan yang kedua yaitu elaborasi, dimana dalam kegiatan ini guru memberikan alat berupa kapas kepada peserta didik guna mempraktikan sub tema tentang gunung dan tanda-tanda hari kiamat. Hal ini dilakukan oleh guru dengan mengajak peserta didik untuk keluar kelas seraya memprkatikan tentang tanda-tanda hari kiamat yang diterangkan dalam surat Al-Qari'ah ayat 5 dengan memberikan sedikit gambaran melalu alat peraga yang berupa kapas. Setelah peserta didik selesai praktik, kemudian guru menyuruh peserta didik untuk membersihkan sampah kapas dari hasil praktik tersebut yang mana hal ini bertujuan agar peserta didik mampu memahami dan menjaga kebersihan alam sekitar serta mengetahui kebesaran dan kekuasaan Allah dalam menciptakan alam semesta ini.

Kegiatan yang terakhir adalah kegiatan konfirmasi. Dalam kegiatan konfirmasi guru memberikan sedikit penjelasan tentang tanda-tanda dari hari kiamat yang kemudian disambung dengan guru memberikan pertanyaan berkaitan dengan materi tersebut, kemudian guru menyimpulkan materi pembelajaran kepada peserta didik seraya memberikan sedikit cerita yang tentang dasyatnya hari kiamat seraya mengkaitkan dengan perilaku peserta didik yang negatif. Hal tersebut bertujuan untuk menumbuhkan keimanan dalam diri peserta didik serta memberikan arahan agar peserta didik mampu untuk melakukan hal-hal yang lebih baik lagi.

3) Kegiatan penutup 
Kegiatan penutup merupakan kegiatan yang terakhir di dalam pelaksanaan pembelajaran. Kegiatan penutup ini dilakukan oleh guru dengan memberikan sedikit pertanyaan terkait tentang kehidupan Rasulullah yang bertujuan agar peserta didik mampu mengingat kembali tentang materi yang telah disampaikan oleh guru pada pembelajaran sebelumnya serta membuat peserta didik untuk lebih mengenal sosok Rasulullah. Kemudian guru memberikan sedikit cerita motivasi tentang semangat para sahabat dan ulama' terdahulu dalam menuntut ilmu, hal ini dilakukan untuk mengali semangat peserta didik dalam menuntut ilmu sehingga peserta didik tidak mengelu dan lebih bersemangat dalam pembelajaran.

Selanjutnya guru mengajak peserta didik untuk muraja'ah surat AlQari'ah ayat 5 beserta artinya secara bersama-sama sebelum menutup pembelajaran, hal ini dilakukan oleh guru guna merefresh kembali hafalan peserta didik dan ketepatan bacaan peserta didik. Dan yang terakhir guru mengajak peserta didik untuk membaca hamdalah, istighfar dan do'a kafaratul majlis sebagai ungkapan rasa syukur atas kelancaran dan kefahaman ilmu yang diberikan Allah melalui proses pembelajaran tersebut serta ungakapan rasa syukur atas dilancarkannya proses pembelejaran tersebut. Kemudian guru mengucapkan salam yang berarti guru telah mengakhiri proses pembelajaran.

Secara garis besar berdasarkan pemaparan di atas dapat ditarik kesimpulan bahwa pelaksanaan pendidikan agama Islam berbasis sirah Nabawiyah yang terealisasikan kedalam kurikulum iman di Kuttab Al-Fatih Semarang sudah sangat baik dan efisien, sebab sebagian besar indikator yang terdapat dalam aspek pelaksanaan kegiatan pendahuluan, kegiatan inti dan penutup sudah sesuai dengan prosedur dalam RKK.

Hal tersebut dapat dilihat dari cara guru menguasai materi, ketepatan penggunaan metode pembelajaran, media yang digunakan, sumber, alokasi waktu pembelajaran, kecakapan guru dalam menciptakan suasana pembelajaran aktif dan menyenangkan yang disesuaikan dengan sub tema yang ada dalam tema pembelajaran, sehingga suasana pembelajaran menjadi menyenangkan dan berjalan dengan lancar serta kecakapan guru dalam menanggapi perilaku peserta didik yang dikaitkan dengan teladan Rasulullah 
atau cerita-cerita Islami sehingga peserta didik mampu mengenal dan mengetahui secara mendalam tentang sosok Rasulullah serta mempraktikan secara langsung materi yang disampaikan oleh guru sesuai dengan teladan Rasul.

\section{SIMPULAN DAN SARAN}

\section{Simpulan}

Berdasarkan dari hasil analisis yang dilakukan oleh peneliti dapat dikesimpulan bahwa secara garis besar Pendidikan Agama Islam yang berbasis sirah Nabawiyah di Yayasan Kuttab Al-Fatih Semarang yang dilaksanakan oleh para guru dengan sangat baik dan efisien, hal ini dapat dibuktikan dari beberapa hal yaitu: Perencanaan Pendidikan agama Islam Berbasis Sirah Nabawiyah di Yayasan Kuttab Al-Fatih Semarang dapat dikatakan sangat baik serta efisien, sebab dalam pelaksanakan perencanaan dalam pembelajaran guru Kuttab sangat memperhatikan prosedur yang akan digunakan dan diterapkan pada peserta didik baik.

Pelaksanaan pendidikan agama Islam Berbasis Sirah Nabawiyah di Yayasan Kuttab Al-Fatih Semarang sangat baik dan efisien, sebab sebagian besar indikator yang terdapat dalam pembelajaran sudah dilaksanakan oleh guru baik dari aspek kegiatan pendahuluan, kegiatan inti maupun kegiatan penutup sudah sesuai dengan prosedur Kuttab.

\section{Saran}

Konsep pendidikan yang diterapkan di Kuttab sesuai dengan arah baru kebijakan pendidikan nasional, yaitupenguatan karakter peserta didik kit, sehingga hal ini dapat dikembangkan atau direplikasikan ke beberapa Lembaga pendidikan, hasil akhirnya akan terwujud sebuah model pendidikan agama islam yang memiliki karakteristik dalam penguatan karakter peserta didik.

\section{DAFTAR PUSTAKA}

Achmadi, P. (2010). Ideologi Pendidikan Islam. Yogyakarta: Pustaka Pelajar.

Azra, A. (2002). Paradigma Baru Pendidikan Nasional. Jakarta: Penerbit Buku Kompas.

Dakir. (2004). Perencanaan dan Pengembangan Kurikulum. Jakarta: PT. Rineka Cipta. 
Depdiknas, B. (2003). I Standar Kompetensi Mata Pelajaran Pendidikan Agama Islam SMP \& MTs. Jakarta: Balitbang Depdiknas.

Baharuddin, M. M. (2011). Pendidikan Humanistik Konsep, Teori dan Aplikasi dalam dunia Pendidikan. Jogjakarta: AR-RUZZMEDIA.

Emzir. (2012). Analisis Data:Metodologi Penelitian Kualitatif. Jakarta: Rajawali Pers.

Grafika, R. S. (2005). Standar Nasional Pendidikan PP No 19 Tahun 2005. Jakarta: Sinar Grafika.

Muflihin, A. (2020). INTERNALISASI NILAI-NILAI KEARIFAN LOKAL PADA PENGEMBANGAN KURIKULUM PENDIDIKAN AGAMA ISLAM. Al-Fikri: Jurnal Studi dan Penelitian Pendidikan Islam, 3(2), 21-32.

Shihab, M. Q. (2006). Wawasan Al-Quran. Bandung: Mizan.

Sugiyono. (2012). Memahami Penelitian Kualitatif. Bandung: Alfabeta.

Sujana, N. (1989). Pembinaan dan Pengembangan Kurikulum di Sekolah. Bandung: Sinar Baru.

Sulaiman, F. H. (1993). Sistem pendidikan Versi Al Ghazali. Bandung: PT. Alma'arif. 